ISSN 0258-7122 (Print), 2408-8293 (Online)

Bangladesh J. Agril. Res. 41(3): 481-489, September 2016

\title{
YIELD PERFORMANCE OF STRAWBERRY GENOTYPES
}

\author{
S. CHOWHAN ${ }^{1}$, M. M. HoSSAIN ${ }^{2}$, M. A. HOQUE ${ }^{3}$ \\ G. RASUL ${ }^{4}$ AND M. S. RONI ${ }^{5}$
}

\begin{abstract}
Five strawberry genotypes ('Rabi 3', 'Camarosa', 'BARI Strawberry 1', 'BADC Strawberry' and 'Festival') were evaluated for their field performance. The maximum number of leaves/plant (14.2), canopy spread $(31.82 \mathrm{~cm})$ and runners/plant (7.2) were found with 'Camarosa', 'Festival' and 'Rabi 3' respectively. Festival took the lowest number of days to flower initiation (32.5). The highest number of flowers (23.64) and fruits/plant (19.98) were found in 'Camarosa'. The heaviest (21.83 g) and the largest sized individual fruit (1539.31 $\mathrm{mm}^{2}$ ) were produced by 'Festival'. Fruit TSS $(\%)$ was the highest (15.83) in BARI Strawberry 1. Genotype 'Festival' gave the highest fruit yield (12.94 t/ha) and 'BADC Strawberry' yielded the lowest $(6.15 \mathrm{t} / \mathrm{ha})$. Considering growth, yield and quality of fruit, genotypes 'Festival' and 'Camarosa' were found promising under the climatic condition of Salna.
\end{abstract}

Keywords: Strawberry genotype, plant growth, fruit yield, fruit quality.

\section{Introduction}

Strawberry (Fragariaxananassa Duch.) is a natural hybrid species that is cultivated worldwide for its aggregate accessory fruits. It is a perennial, stoloniferous herb belonging to the Rosaceae family. The fruit is widely cultivated in the temperate and subtropical regions in many parts of the world. They are grown throughout Europe, the United States, as well as in Canada and South America. In India, it is generally cultivated in the hills of some states. The wide variation in climates within these regions and the wide adaptation of the strawberry plant permit harvesting and marketing the fruit during greater part of the year (Rahman, 2011). Strawberry is a minor exotic fruit in Bangladesh. A small scale research and development in the public and private sector is now going on. Bangladesh Agricultural Research Institute (BARI) has developed a variety named BARI Strawberry 1, Rajshahi University has developed three varieties, namely Rabi 1, Rabi 2 and Rabi 3 and BAU also developed a variety viz. FTIP-BAU-Strawberry. It is now cultivated in many parts of Bangladesh. There has been a bright prospect of farming strawberry, a high-value crop, everywhere in the country except the coastal districts. Strawberry farming has started gaining popularity in all over the country. In Bangladesh, only a few

${ }^{1}$ Division of Adaptive Research and Extension, Bangladesh Institute of Nuclear Agriculture, ${ }^{2,3 \& 5}$ Department of Horticulture, ${ }^{4}$ Department of Genetics and Plant Breeding, Bangabandhu Sheikh Mujibur Rahman Agricultural University, Gazipur, Bangladesh. 
varieties of strawberry are being cultivated, besides there are some other genotypes too; which have higher yield compared to the released varieties (Biswas et al., 2010). Early fruit bearing flower initiation, more number of fruit set, runner production, fruit weight, size, shape etc. are inherent characters; all of these contribute to yield. Different genotypes have different genetic potential. Potential yield of strawberry is not possible mainly due to climatic factors. Genotypes which have high adapting power to a wide range of environmental conditions i.e. biotic and abiotic and got better acclimatizing capacity will surely perform better. As strawberry is a temperate fruit its performance in terms of growth, yield, quality, and propagation in the tropics and subtropics are required to find out the most suitable genotype. To cultivate strawberry in Bangladesh, research on selection of appropriate genotype is the prerequisite for its commercialization. Hence, the present investigation has been carried out to find out the best genotype for optimum growth and higher yield of strawberry.

\section{Materials and Method}

The present investigation was carried out at the Horticulture Research Farm, Bangabandhu Sheikh Mujibur Rahman Agricultural University, Salna, Gazipur during the period from November 2011 to March 2012. Five genotypes, 'Rabi 3', 'Camarosa', 'BARI Strawberry 1', 'BADC Strawberry' and 'Festival', respectively were used as treatments. The experiment was laid out in a Randomized Complete Block Design with four replications. The whole experimental area was divided into four blocks representing four replications. The unit plot size was $6.0 \mathrm{~m} \times 1.2$ $\mathrm{m}$ accommodating 40 plants in each plot having row and plant spacing of $60 \mathrm{~cm}$ $\times 30 \mathrm{~cm}$ respectively. The unit plots and blocks were separated by $0.5 \mathrm{~m}$ and 0.75 $\mathrm{m}$ respectively. Full dose of cow dung (37 t/ha) and DAP (640 kg/ha) and half of MoP (333 kg/ha) were applied at final land preparation and rest of MoP in two installments. Intercultural operations are done as necessity. Data collection was started after 20 days of sapling planting i.e. January 08, 2012 at 10 days interval. Ten plants were selected randomly from each plot and data were recorded on individual plant basis from the selected plants in respect of: number of leaves/plant, canopy spread $(\mathrm{cm})$, number of runners/plant, days to flower initiation, number of flowers/plant, number of fruits/plant, weight of individual fruit $(\mathrm{g})$ and size of fruit $\left(\mathrm{mm}^{2}\right)$ from 10 randomly selected matured fruits of the selected plants. Fruit color ( $1=$ Very light red, $3=$ Light red, $5=$ Intermediate red, $7=$ Dark red and $9=$ Very dark red) and shape ( $1=$ Kidney shape, $2=$ Oblate, $3=$ Round, 4= Conical, 5= Bi-conical, 6= Almost cylindrical, $7=$ Wedged, $8=$ Ovoid, $9=$ Cordate) was recorded by eye observation according to IBPGR (1986) scale, yield/plant (g), yield/plot (kg), yield (t/ha) and TSS (\%). The collected data were analyzed with the help of computer using MSTATC program and mean 
separation was done by Duncan's Multiple Range Test (DMRT) at 5\% level of probability.

\section{Results and Discussion}

The results obtained from the present investigation have been presented and discussed character wise under separate headings.

\section{A. Qualitative Characters}

Table 1. Qualitative characteristics of strawberry genotypes

\begin{tabular}{l|c|c|c|c}
\hline \multirow{2}{*}{ Genotypes } & \multicolumn{2}{|c|}{ Fruit colour } & \multicolumn{2}{c}{ Fruit shape } \\
\cline { 2 - 5 } & Score* & Remarks & Score** & Remarks \\
\hline Rabi 3 & 5.25 & Intermediate red & 5.07 & Bi conical \\
Camarosa & 4.98 & Intermediate red & 5.68 & $\begin{array}{c}\text { Bi conical to Almost } \\
\text { cylindrical }\end{array}$ \\
BARI Strawberry 1 & 5.88 & $\begin{array}{c}\text { Intermediate to Dark } \\
\text { red }\end{array}$ & 5.03 & $\begin{array}{c}\text { Bi conical } \\
\text { BADC Strawberry }\end{array}$ \\
Festival & 4.04 & $\begin{array}{c}\text { Light to Intermediate } \\
\text { red }\end{array}$ & 4.87 & Conical to Bi conical \\
& 4.67 & $\begin{array}{c}\text { Light to Intermediate } \\
\text { red }\end{array}$ & 5.62 & $\begin{array}{c}\text { Bi conical to Almost } \\
\text { cylindrical }\end{array}$ \\
\hline
\end{tabular}

*Fruit color score: $1=$ Very light red, $3=$ Light red, $5=$ Intermediate red, $7=$ Dark red, 9 $=$ Very dark red.

**Fruit shape score: 1 = Kidney, $2=$ Oblate, $3=$ Round, $4=$ Conical, $5=$ Bi-conical, $6=$ Cylindrical, $7=$ Wedged, $8=$ Ovoid, $9=$ Cordate

\section{B. Quantitative Characters}

\section{Number of leaves per plant}

The number of leaves per plant differed significantly among genotypes (Table 2). The maximum number of leaves (14.20) per plant was recorded from the genotype 'Camarosa' which was statistically identical to 'Festival' and the minimum per plant was from the genotype 'BADC Strawberry' (8.59) which was statistically identical to 'Rabi 3'. The number of leaves per plant in different genotypes varied mainly due to inherent characters of the genotypes. In Fig. 2. all the genotypes showed more or less similar increasing trend up to 50 DAP and then a tremendous increase in number of leaves in the genotype 'Camarosa' and 'Festival' up to 80 DAP. Other genotypes 'BARI Strawberry 1', 'Rabi 3' and 'BADC Strawberry' showed a similar trend of increasing number of leaves up to 80 DAP. 


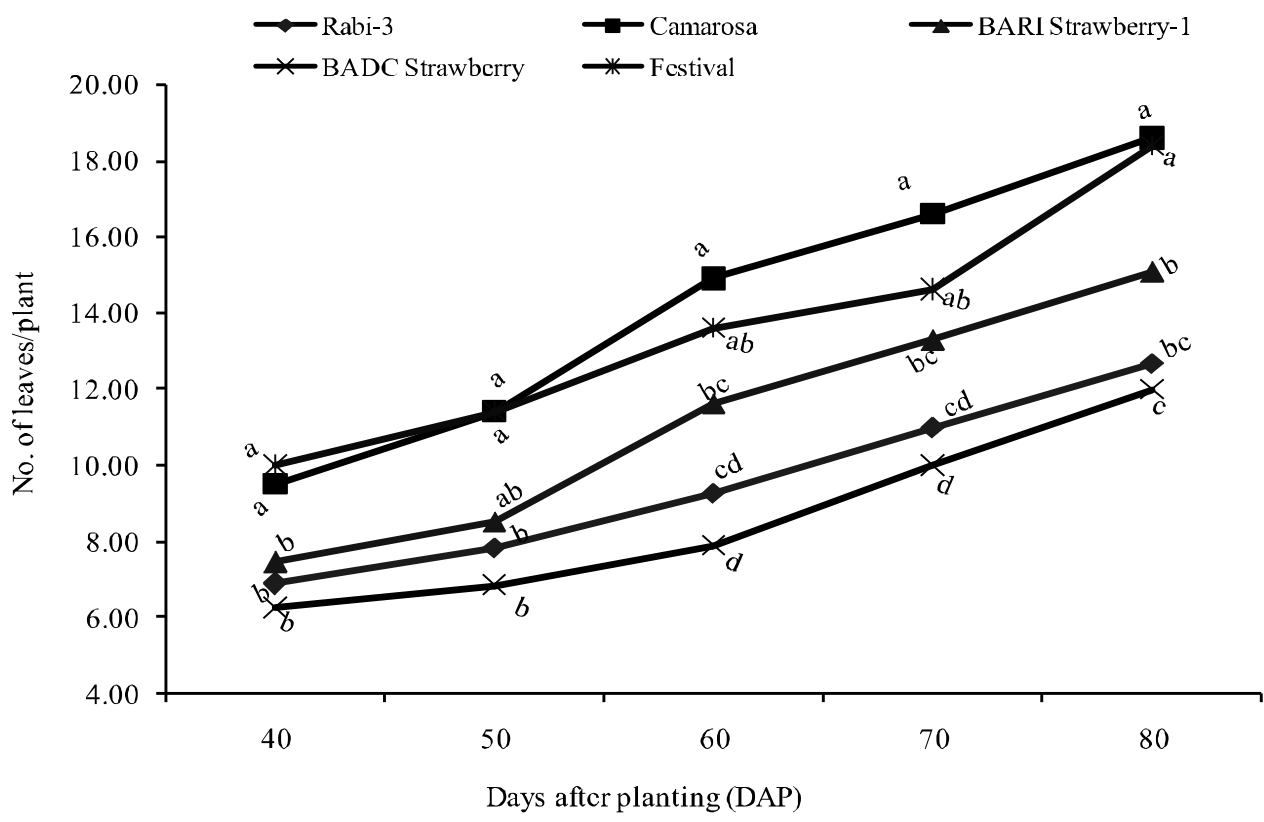

Fig. 1. Number of leaves per plant of strawberry genotypes at different days after planting.

Means bearing same letter(s) in a column do not differ significantly at 5\% level of probability by DMRT.

\section{Canopy spread}

Canopy spread was significantly influenced by different genotypes (Table 2). Maximum (31.82 cm) canopy spread was produced by genotype 'Festival' followed by 'Rabi-3' $(29.94 \mathrm{~cm})$ and 'Rabi 3' $(23.99 \mathrm{~cm})$. Whereas minimum canopy spread was found in 'BADC Strawberry' $(22.45 \mathrm{~cm})$ which was statistically identical to the genotype 'BARI Strawberry 1'. Variation in canopy spread was mainly due to inherent characters of the genotypes. Canopy spread was in an uprising trend for all genotypes at different days after planting (DAP) (Fig. 2). It is noted that at 70 and 80 DAP canopy spread for all the genotypes became static.

\section{Runners per plant}

The number of runners per plant of strawberry genotypes differed significantly (Table 2). The maximum number of runner was found in 'Rabi 3' (7.20) and whereas the minimum was in genotype 'Camarosa' (1.20) and no runner was produced by genotype 'Festival' which was statistically inferior. Genotypes 'BARI Strawberry 1 ' and 'BADC Strawberry' were statistically identical which produced moderate number of runners. Das et al. (2007) found that the average number of 
runners per plant in different genotypes varied from 0.3 to 9.4 and Biswas et al. (2010) reported it between 0.0 to 31.33. Number of runners per plant had an increasing trend for all the genotypes up to 60 DAP (Fig. 4) except for 'Camarosa' and 'Festival'. At 70 DAP all the genotypes had a declining trend which was mainly due to end of growing season and vegetative growth.

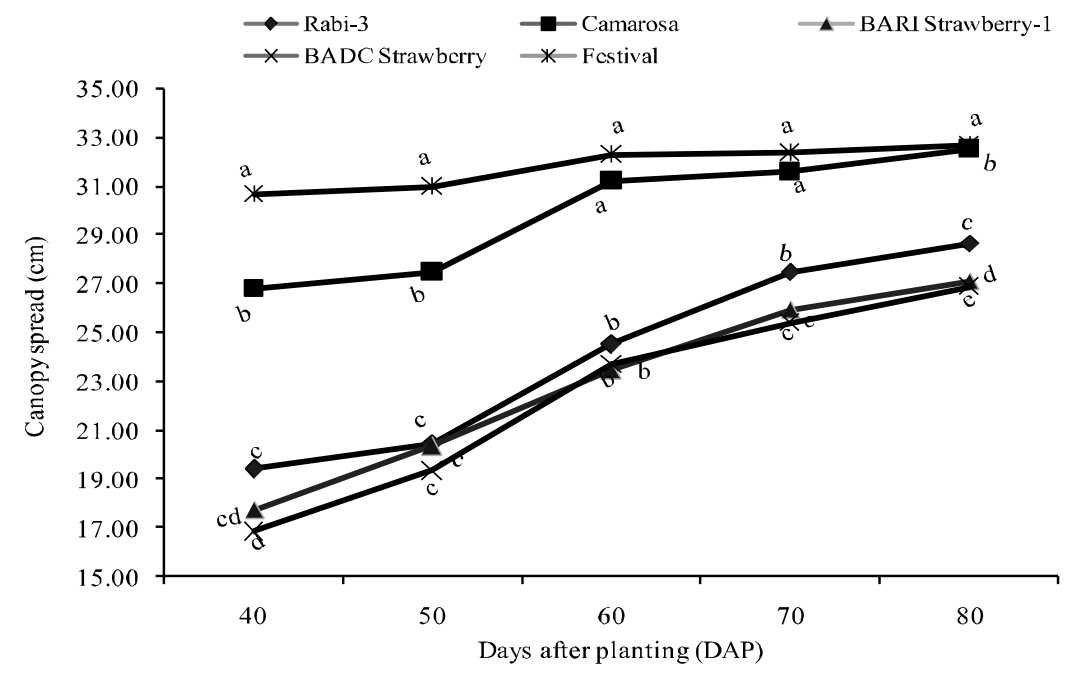

Fig. 2. Canopy spread of strawberry genotypes at different days after planting.

Means bearing same letter(s) in a column do not differ significantly at 5\% level of probability by DMRT.

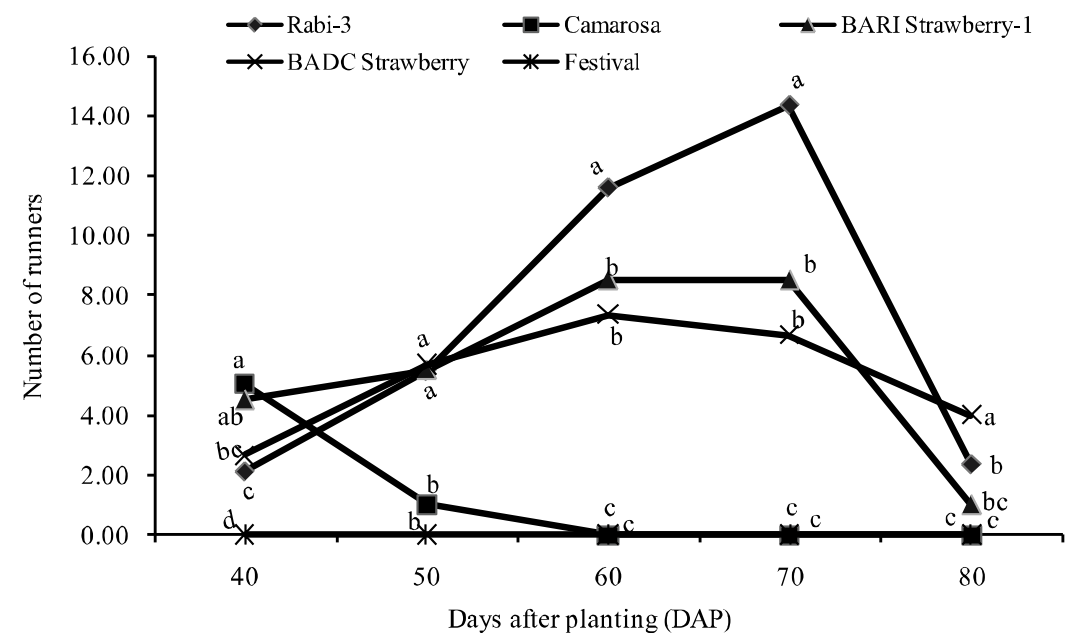

Fig. 3. Number of runners per plant of strawberry genotypes at different days after planting.

Means bearing same letter(s) in a column do not differ significantly at 5\% level of probability by DMRT. 
Table 2. Growth characteristics of five strawberry genotypes

\begin{tabular}{l|c|c|c|c|c|c}
\hline \multicolumn{1}{|c}{ Genotypes } & $\begin{array}{c}\text { No. of } \\
\text { leaves/ } \\
\text { plant }\end{array}$ & $\begin{array}{c}\text { Canopy } \\
\text { spread } \\
(\mathrm{cm})\end{array}$ & $\begin{array}{c}\text { No. of } \\
\text { runners/ } \\
\text { plant }\end{array}$ & $\begin{array}{c}\text { Days to } \\
\text { flower } \\
\text { initiation }\end{array}$ & $\begin{array}{c}\text { No. of } \\
\text { flowers/ } \\
\text { plant }\end{array}$ & $\begin{array}{c}\text { No. of } \\
\text { fruits/plant }\end{array}$ \\
\hline Rabi 3 & $9.53 \mathrm{c}$ & $23.99 \mathrm{c}$ & $7.20 \mathrm{a}$ & $44.95 \mathrm{c}$ & $15.45 \mathrm{~b}$ & $11.28 \mathrm{~b}$ \\
Camarosa & $14.20 \mathrm{a}$ & $29.94 \mathrm{~b}$ & $1.20 \mathrm{c}$ & $36.80 \mathrm{~d}$ & $23.64 \mathrm{a}$ & $19.98 \mathrm{a}$ \\
(BARI & $11.20 \mathrm{~b}$ & $22.94 \mathrm{~d}$ & $5.60 \mathrm{~b}$ & $49.63 \mathrm{~b}$ & $11.49 \mathrm{c}$ & $7.41 \mathrm{c}$ \\
Strawberry 1 & & & & & & \\
BADC & $8.59 \mathrm{c}$ & $22.45 \mathrm{~d}$ & $5.30 \mathrm{~b}$ & $62.29 \mathrm{a}$ & $6.06 \mathrm{~d}$ & $3.45 \mathrm{~d}$ \\
Strawberry & $13.60 \mathrm{a}$ & $31.82 \mathrm{a}$ & $0.00 \mathrm{~d}$ & $32.50 \mathrm{e}$ & $10.56 \mathrm{c}$ & $6.86 \mathrm{c}$ \\
Festival & $*$ & $*$ & $*$ & $*$ & $*$ & $*$ \\
\hline $\begin{array}{l}\text { Level of } \\
\text { Significance }\end{array}$ & 4.82 & 1.77 & 16.14 & 2.23 & 4.83 & 5.43 \\
\hline CV \% &
\end{tabular}

Means bearing same letter(s) in a column do not differ significantly at $5 \%$ level of probability by DMRT.

\section{Days to flower initiation}

Days to flower initiation differed significantly among the genotypes (Table 2). The maximum days of 62.29 were required for flower initiation by the genotype 'BADC Strawberry' followed by 'BARI Strawberry 1' (49.63 days), 'Rabi 3' (44.95 days) and 'Camarosa' (36.80 days). The minimum days to flower initiation were in genotype 'Festival' (32.50 days) which was statistically different to other four genotypes. Days to flower initiation in different genotypes varied mainly due to inherent characters of the genotypes, stage of growth, day length and temperature. Rahman and Ahmad (2010) found that days to flower initiation in fifteen strawberry lines were between 44 to 90 days.

\section{Flower per plant}

Significant influence of genotypes was observed on flowers per plant (Table 2). The maximum number of flowers per plant of 23.64 recorded in $\mathrm{V}_{2}$ (Camarosa) which was followed by 'Rabi 3'. Genotype 'BARI Strawberry 1' and 'Festival' was statistically identical and produced almost equal number of flowers per plant. The minimum number of flower (6.06) was produced by the genotype 'BADC Strawberry'; which was statistically inferior. The number of flowers/plant in different genotypes varied mainly due to inherent characters of the genotypes. Verma et al. (2002) found the number of flowers/plants ranged from 3.20-6.69 in different genotypes. Whereas, Rahman and Ahmad (2010) found 1 to 24 flowers per stalk in fifteen strawberry lines. 


\section{Fruit per plant}

Fruits per plant is one of the most important yield contributing characters in all fruits and as well as strawberry. The genotypes significantly differed for fruit set per plant (Table 2). The highest 19.98 fruits per plant was observed in the genotype 'Camarosa' and the lowest in the genotype 'BADC Strawberry' 3.45. Rahman and Ahmad (2010) recorded 4 to 27 fruits per plant in fifteen strawberry lines which are in agreement with the present investigation.

\section{Weight of individual fruit}

As regards to the individual fruit weight, it was observed that it varied significantly differed for genotypes and ranged from $11.64 \mathrm{~g}$ to $21.83 \mathrm{~g}$ (Table $3)$. The heaviest fruit weight of $21.83 \mathrm{~g}$ was found in the genotype 'Festival' and the lightest of $11.64 \mathrm{~g}$ was recorded in 'BADC Strawberry' which was statistically identical to the genotype 'BARI Strawberry 1' and 'Rabi 3'. This result agrees with the findings of Maurer and Umeda (1997). They harvested strawberry fruit weight ranged from $10.6 \mathrm{~g}$ to $11.63 \mathrm{~g}$. Biswas et al. (2010) in another experiment found that, fruit weight in five genotypes ranged from $12.03 \mathrm{~g}$ to $24.13 \mathrm{~g}$.

\section{Size of fruit (length and width)}

The fruit size is varied significantly among the genotypes (Table 3). The largest fruit size of $1539.31 \mathrm{~mm}^{2}$ was recorded in the genotype 'Festival' which was significantly different from rest of the genotypes. The smallest fruit size of $921.29 \mathrm{~mm}^{2}$ was recorded in the genotype 'BADC Strawberry'. Asrey and Singh (2004) found fruit size (fruit length and width) of different genotypes ranged from $1016 \mathrm{~mm}^{2}$ to $1431.4 \mathrm{~mm}^{2}$. Biswas et al. (2010) reported that fruit size of five strawberry genotypes varied between $738 \mathrm{~mm}^{2}$ to $2072.02 \mathrm{~mm}^{2}$; which supports the present findings.

\section{Total Soluble Solids (TSS)}

A significant variation was observed regarding the TSS (\%) among the genotypes (Table 3). The highest TSS (15.83\%) was recorded from the genotype 'BARI Strawberry 1 '. The minimum fruit TSS $(9.98 \%)$ was in the genotype 'Festival' which was statistically similar to the genotype 'Camarosa'. Fruit TSS percent varied mainly due to inherent control of the genotypes. Waliullah et al. (2011) found fruit TSS per cent of strawberry ranged from 9.33 to 12.33 in different genotypes including BARI Strawberry 1. 
Table 3. Fruit characteristics of five strawberry genotypes

\begin{tabular}{l|c|c|c}
\hline \multicolumn{1}{c|}{ Genotypes } & $\begin{array}{c}\text { Weight of individual } \\
\text { fruit }(\mathbf{g})\end{array}$ & Size $\left(\mathbf{m m}^{\mathbf{2}}\right)$ & Fruit TSS (\%) \\
\hline Rabi 3 & $13.86 \mathrm{bc}$ & $1014.99 \mathrm{~b}$ & $12.74 \mathrm{~b}$ \\
Camarosa & $16.38 \mathrm{~b}$ & $1139.02 \mathrm{~b}$ & $12.20 \mathrm{bc}$ \\
BARI Strawberry 1 & $13.31 \mathrm{bc}$ & $1027.02 \mathrm{~b}$ & $15.83 \mathrm{a}$ \\
BADC Strawberry & $11.64 \mathrm{c}$ & $921.29 \mathrm{~b}$ & $13.16 \mathrm{~b}$ \\
Festival & $21.83 \mathrm{a}$ & $1539.31 \mathrm{a}$ & $9.98 \mathrm{c}$ \\
\hline Level of Significance & $*$ & $*$ & $*$ \\
\hline CV \% & 11.44 & 12.40 & 9.34 \\
\hline
\end{tabular}

Means bearing same letter(s) in a column do not differ significantly at $5 \%$ level of probability by DMRT.

\section{Fruit yield per hectare}

Fruits yield per hectare was significantly differed in different strawberry genotypes. Among the entries, the genotype 'Festival' produced the highest fruit yield of 12.94 ton per hectare which was statistically similar to Camarosa. The lowest yield of 6.15 ton per hectare was obtained from the genotype 'BADC Strawberry' which was inferior. Legard et al. (2000) harvested fruits of three strawberry cultivars and obtained a yield ranged from $14.81-22.38$ ton per ha which supports the above findings of the present investigation.

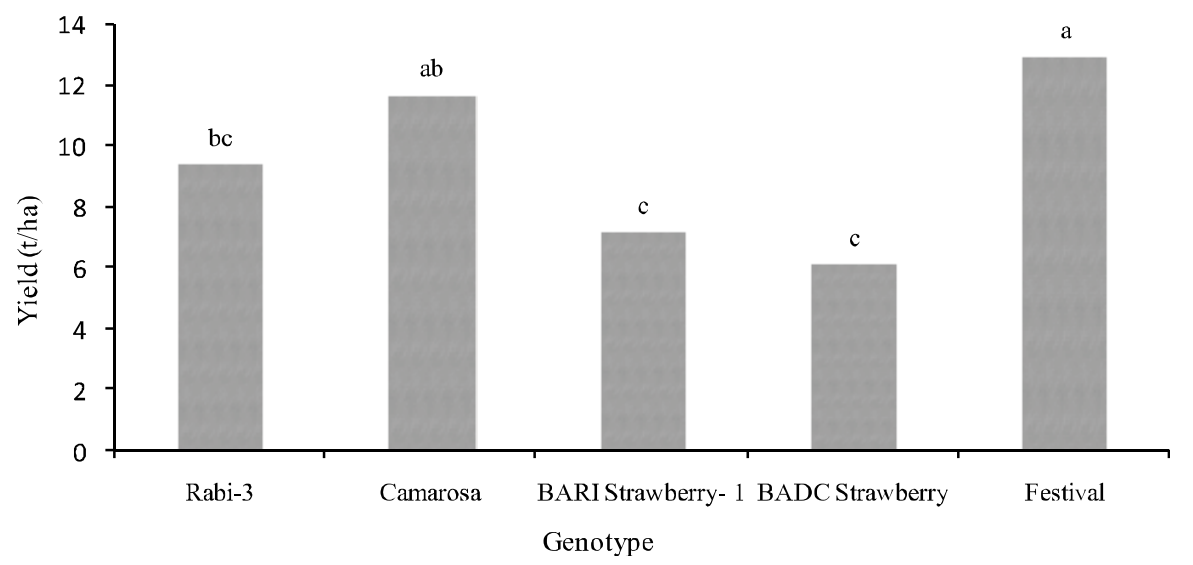

Fig. 4. Yield of different strawberry genotypes.

Means bearing same letter(s) in a column do not differ significantly at 5\% level of probability by DMRT.

\section{Conclusion}

Among the five genotypes studied, 'Festival' was the highest yielder compared to others genotypes. Genotype 'Camarosa' had the maximum number of flower and 
fruit set. The number of runners per plant increased up to 60 DAP for all genotypes except 'Camarosa' and 'Festival'. So, these two genotypes are difficult to propagate through runners.

\section{Acknowledgments:}

We are grateful to the Ministry of Science, Information and Communication Technology, Govt. of the People's Republic of Bangladesh for their financial support.

\section{References}

Biswas, G. C., M. A. Uddin and M. S. Akhter. 2010. Regional Yield Trial of Strawberry. Research Report on Horticultural Crops. BARI, Joydebpur, Gazipur-1701. Pp. 334335.

International Board for Plant Genetic Resource (IBPGR). 1986. Characterization and preliminary evaluation of Strawberry. [Collected from browsing websitehttp://www2.bioversityinternational.org/publications/Web_version/257/ch4.htm\#bm 24.\%20Plant\%20Data].

Legard, D. E., C. L. Xiao, J. C. Mertely and C. K. Chandler. 2000. Effects of Plant Spacing and Cultivar on Incidence of Botrytis Fruit Rot in Annual Strawberry. Plant Disease, University of Florida, Gulf Coast Research and Education Center, 13138 Lewis Gallagher Road, Dover 33527, Pp. 531-538.

Maurer, M. A. and K. Umeda. 1997. Influence of cultivars and planting date on strawberry growth and development in the low desert. Vegetable report, Uni. of Arizona College of Agriculture. [Cited from- http://ag.arizona.edu/pubs/crops/azl 143].

Rahman, L. 2011. Production technology of strawberry in Bangladesh. An unpublished Ph.D. Thesis. Department of Horticulture, Bangabandhu Sheikh Mujibur Rahman Agricultural University, Salna, Gazipur-1706.

Rahman, M. M. and M. R. Ahmad. 2010. Collection and Evaluation of Strawberry Lines. Research Report on Horticultural Crops. BARI, Joydebpur, Gazipur-1701. Pp. 329331.

Verma, S. K., R. K. Singh and R.R. Arya. 2002. Variability and correlation studies in strawberry germplasm for quantitative traits. Indian J. Hortic. 59(1): 39-43.

Waliullah, M. H., M. A. Uddin and M. R. Zaman. 2011. Regional Yield Trial of Strawberry. Research Report on Horticultural Crops. BARI, Joydebpur, Gazipur1701. Pp. 369-370. 